\title{
The Condition of Polish Autobiographical Documentaries - More Similar to a Reality Show?
}

The variety of texts devoted to documentary film-making prove that the interest in this area of cinematography ${ }^{1}$ has many different aspects. Polish autobiographical documentary ${ }^{2}$ has recently occupied a special place among these studies. In our opinion, the interesting connections between documentary film and the development of television, which clearly meet in the field of genres appearing on the small screen, strongly manifest themselves in this area. Autobiographical documentary, in many respects resembling a reality show, may be regarded as an authorial response of young directors to this - voyeurism celebrating - television genre.

The aim of this article is to outline the similarities and differences between an autobiographical documentary and a reality show on the basis of a case study ${ }^{3}$, which is a very popular approach in media studies. Łukasz Konopa's film Moje dwadzieścia okrązeń (Eng. My twenty laps, 2008) will be used as research material. The article consists of four parts: the first briefly introduces the essence of autobiographical documentary, the second focuses on the reality show, the third analyses Konopa's film, and the fourth constitutes a summary of considerations made in the text.

* Dr, e-mail: bogumilafl@gmail.com; dr, e-mail: agabarczyk@gmail.com; The University of Lodz, Faculty of Philology, Department of Journalism and Communication; ul. Pomorska 171/173, 90-236 Łódź.

${ }^{1}$ For example: B. Fiołek-Lubczyńska, „Tradycja i nowatorstwo współczesnego polskiego kina dokumentalnego (po 1989 r.) Bliżej rzeczywistości, bliżej człowieka...”, in: „O mediach i komunikacji. Skrypt dla studentów dziennikarstwa i komunikacji społecznej”, ed. E. Pleszkun-Olejniczakowa, J. Bachura, M. Worsowicz, Wydawnictwo Uniwersytetu Lódzkiego, Lodz 2010.

${ }^{2}$ We have already devoted several texts and papers to this variety of documentary film: A. Barczyk, B. Fiołek-Lubczyńska, "Film of facts and film of fictions - two pictures of catharsis in film", a speech during the I International Congress in Comparative Studies "Human in Language, Literature, Culture” (Daugavpils, 14-16.11.2013 r.); A. Barczyk, R. Nolbrzak, „Przed kamerą zamiast na kozetce u psychologa? Terapeutyczna funkcja polskich dokumentów autobiograficznych”, a speech during Ogólnopolska Sesja Naukowa Kinoanaliza (Lodz, 22-24.11.2013 r.).

${ }^{3}$ See: R.D. Wimmer, J.R. Dominick, „Mass media. Metody badań”, transl. T. Karłowicz, Wydawnictwo Uniwersytetu Jagiellońskiego, Cracow 2008, p. 191. 


\section{Polish autobiographical documentary ${ }^{4}$}

When asked about his opinion on the subject of the present-day documentary film, Andrzej Fidyk, one of the leading Polish documentary film-makers, observed a distinct tendency in Polish non-fiction cinema; it consists in the fact that artists create films about their own families ${ }^{5}$. Equipped with small sound recorders and cameras, the directors enter their own homes not as family members but, above all, as film-makers. They are not only behind the camera, but often in front of it - next to their parents and other household members, turning them into the characters of their audiovisual fantasies. Mirosław Przylipiak draws attention to the relevance and freshness of this phenomenon; in his book Poetyka filmu dokumentalnego, he writes that the new variant of saturating the documentary with its author's individuality has appeared relatively recently:

It consists in the fact that the authors of documentary films tell stories about themselves. In order to realize the importance of this formula, we must remember that for a long time the recent "personal" films, that is statements telling the story of their author from the first person perspective, so to speak, almost did not exist in documentary film-making ${ }^{6}$.

Even a casual look at the history of film reveals that technological changes have had a significant impact on the development of this phenomenon - the appearance (and then the popularization) of small, light cameras, which allowed films to be made in ordinary houses, and of sound registering equipment synchronized with them made it possible for artists to create such documentaries ${ }^{7}$. Agniesza Wiśniewska - following in Mirosław Przylipiak's footsteps - makes an attempt to reconstruct the history of autobiographical documentary. Diaries, the 1982 film, lasting almost three hours, created by the American director Ed Pincus, is recognized as the first production to represent this trend. For five years (1971-1976), the author filmed his life, and the lives of his loved ones, recording the most sensitive moments of his marriage. He used a $16 \mathrm{~mm}$ camera and a port-

\footnotetext{
${ }^{4}$ We use a brief study on the subject of autobiographical documentary, which also appears in our different texts, in this part of the article.

${ }^{5}$ See: „Reality show kontra film dokumentalny”, [online], http://www.stopklatka.pl/wydarzenia/wydarzenie.asp?wi=68883 [access: 31.03.2012].

${ }^{6}$ M. Przylipiak, „Poetyka kina dokumentalnego”, $2^{\text {nd }}$ ed., en., rev. ed., Wydawnictwu Uniwersytetu Gdańskiego, Gdansk-Slupsk 2004, p. 199.

${ }^{7}$ See: A. Wiśniewska, „«Takiego pięknego syna urodziłam» Marcina Koszałki, czyli zaprzepaszczony potencjał krytyczny dokumentu autobiograficznego”, in: „Polskie kino dokumentalne 1989-2009. Historia polityczna”, ed. A. Wiśniewska, Wydawnictwo Krytyki Politycznej, Warsaw 2011, p. 59 .
} 
able tape recorder ${ }^{8}$. As Wiśniewska writes, "Ed Pincus inspired many creators who reached for cameras so as to record their lives, or actually the problems connected with them"'. Autobiographical documentary has made a considerable career in the USA, yet in Poland these kinds of films are much less prevalent. Mirosław Przylipiak counts the following among them: Marcin Latałło's Ślad (Eng. A trace), Piotr Kielar's Tata z Ameryki (Eng. Dad from America), Wojciech Staroń's Syberyjska lekcja (Eng. Siberian lession), Pawel Łoziński’s Siostry (Eng. The Sisters) and Koszałka's Takiego pięknego syna urodziłam ${ }^{10}$ (Eng. I gave birth to such a beautiful son).

\section{Reality show - specification of the genre and its contents}

The irresistible need to make the private sphere public, perfectly exemplified by the activities of social network ${ }^{11}$ users, was not invented in the twentyfirst century. Its roots may be found much earlier, even in the nineteenth century, when: "The psychoanalyst's couch [...] started to serve as a confessional of sorts" ${ }^{\prime 2}$. The means of mass communication tried to adjust to the needs of the recipients - the entertainment function ${ }^{13}$ joined those of informing and directing public opinion in typologies of media functions relatively quickly. Bored with fictional broadcasts, the viewership eventually started to expect the media to present "real life". The reality show became one of the responses to this need.

Fundamental problems with classifying television genres result from the wealth of literary and film studies, whose achievements still influence that area. "Just as television was preceded in its development by radio, the reality show programmes descend from radio broadcasts. In 1948, the radio genre candid microphone gave rise to a television programme Candid Camera"14. Subsequent serious attempts at adjusting the new genre to the needs of television took place in the 1970s when "The cameras were installed in the house of Mr. and Mrs. Loud

\footnotetext{
${ }^{8}$ See: ibid., p. 59.

${ }^{9}$ Ibid, p. 60.

${ }^{10}$ See: ibid.

${ }^{11}$ The facebook wall, where users publish posts, often becomes a vessel for extraordinarily personal information (descriptions of one's actions, memories, reflections), both of a visual and textual character.

${ }^{12}$ M. Krzpiet, „Fenomen ekshibicjonizmu w telewizji”, Impuls, Cracow 2005, p. 24.

${ }^{13}$ This function, absent in H.D. Laswell's typology (1948), appears in Ch. R. Wright's proposal (1959). See: M. Mrozowski, „Media masowe. Władza, rozrywka i biznes”, Oficyna Wydawnicza Aspra JR, Warsaw 2001, p. 114.

${ }^{14}$ K. Łuszczek, „Nowoczesna telewizja, czyli bliskie spotkania z kulturą masową”, Maternus Media, Tychy 2004, p. 26.
} 
from Santa Barbara in California. 12 episodes were made under the common title of An American Family. The viewers could watch the utter disintegration of family bonds. This triggered protests and criticism of the producers' actions" ${ }^{\text {"15. The }}$ genre that was supposed to show "real life" became "a game of life"16.

Jerzy Uszyński points out that the reality show is a "Spectacle of new generation, heterogenic in character and somewhat difficult to define. It contains processed elements of other genres, at the same time being at the intersection of types of television, and constitutes a self-contained wonder"17. The heterogenic character of this genre stems from the combination of three elements: observation, interaction and game ${ }^{18}$. Internal tensions between these spheres may be revised in different ways within a particular production, affecting attempts to define the reality show ${ }^{19}$ undertaken by theorists. In spite of the aforementioned differences between individual programmes, it is possible to describe the genre by means of a plot-related pattern ${ }^{20}$ and outline its basic indicators:

- The characters of a reality show are non-professional actors with no experience in acting, who are supposed to constitute a "sample of society";

- A Reality show presents "the everyday life of characters", which in reality consists of situations contrived for the needs of the programme;

- The recording is edited, increasing the pace and attractiveness of the image which reaches the recipient;

- The viewer - just like the camera - is situated as a "voyeur" who follows the lives of the characters with great interest;

- Pushing the limits of intimacy and the accompanying exhibitionism of the characters (the hallmark of our times, largely because of the internet which allows everyone to become the sender of public content) are often linked with controversies, which boost audiences.

The element of observation - "traditionally attributed to documentaries" 21 - is also updated in the field of the reality show, even though the reality we are dealing with in this case (through the desire to "fish out" conflict situations, which are controversial as a consequence) becomes artificial and created.

\footnotetext{
${ }^{15}$ Ibid, p. 27.

${ }^{16}$ R. Sulima, „Oko 'Wielkiego Brata”, in: „Podglądanie 'Wielkiego Brata”, ed. W. Godzic, Rabid, Cracow 2001, pp. 27-28. Cyt. za: K. Łuszczek, op. cit., p. 27.

${ }^{17}$ J. Uszyński, „Telewizyjny pejzaż genologiczny”, Telewizja Polska S.A. Centrum Strategii Akademia Telewizyjna, Warsaw 2004, p. 127.

${ }^{18}$ See: ibid., p. 128.

${ }^{19}$ Uszyński points out that in the examination of examples such as Big Borther, it may be assumed that it is "a spectacle based on a psychological game between the participants. In practice, the term reality show has become customary, emphasizing the element of peeking at reality rather than at the psychological game". See: J. Uszyński, p. 128.

${ }^{20}$ This pattern can be found in J. Uszyński’s work. See: J. Uszyński, op. cit., pp. 128-129.

${ }^{21}$ Ibid., p. 128.
} 


\section{The case of Lukasz Konopa}

The present-day viewer, who already knows Marcin Koszałka's shocking documentary Takiego pięknego syna urodziłam (1999)22, will not be surprised by Łukasz Konopa's story. Moje dwadzieścia okrażeń is a peculiar portrait of a family, somewhat resembling a confession, but simultaneously different in many respects, mainly due to the lack of the author's presence in the film ${ }^{23}$. Konopa does not appear in his film in a direct way; Ewa reminds the viewer of his presence by talking to her son. Konopa's documentary is also different from Koszałka's film in the mother's approach to the filming ${ }^{24}$.

Konopa paints a picture of his parents with the camera. The mother - "Ewa Przepiórska-Konopa, an energetic, middle-aged blonde, a general practitioner in a small village near Warsaw"25. The father - Stanisław, is the opposite of his wife: "a court-appointed physician, withdrawn, with a grim outlook on life, probably because of his profession" 26 . Neither of them - as in the case of the reality show programmes - had ever dealt with a camera before ${ }^{27}$. Konopa portrays concrete characters, whilst simultaneously asking a universal question: how is it possible for such different people to be in a happy relationship? ${ }^{28}$

Moje dwadzieścia okrążen registers the ordinary life of its characters; just like reality shows, it features created and contrived elements. One may assume the initial

${ }^{22}$ The very idea of the film - alluding (e.g. through the use of the ubiquitous camera) to the poetics of reality show - seemed particularly shocking, which is pointed out by, among others, A. Piotrkowska: "It is not so much the content that is shocking as the concept of implementation". See: A. Piotrowska, „Wiwisekcja”, Tygodnik Powszechny 2000, No. 8, p. 13.

${ }^{23}$ Koszałka is a fully fledged character of his film (he often appears in the frame), entangled in the problematic relations which bind his family.

${ }^{24}$ Koszałka's mother has a negative attitude to the process and repeatedly expresses her discontent. Ewa, on the other hand, asks to be filmed, e.g. saying "Now I am going to jump through the bush. Did you film it?".

${ }^{25} \mathrm{Http}: / /$ www.filmpolski.pl/fp/index.php/4223470 [access: 3.04.2012].

${ }^{26}$ Ibid. Halfway through the film the married couple has a conversation concerning the attitude to patients. Stanisław, distanced from the world, says about himself: "The father has a lousy job". He often recalls descriptions of bodies he performed an autopsy on. A scene in which he dictates an opinion about the corpse to his assistant deserves particular attention: "As a court-appointed physician, a surgery expert witness, I performed an external examination of the corpse. I found the following injuries...". It resembles the first scene of the documentary in terms of composition: there are two characters in the frame, a text is being presented (a poem in the former, a report in the latter); it is one of the first scenes to introduce Stanisław. He has become accustomed to death; he approaches it rationally since he sees it every day. Ewa is trying to rationalize this issue in order to comfort her patients.

27 Just like the local patients who appear in the documentary.

28 At the end of the film, his mother answers the question: "Me and your dad are completely different and perhaps that is why we are so happy with each other. Because I am an extreme optimist, and he is an extreme pessimist". 
scene to be such an element; it introduces us to the main character - the author's mother. Located in the left side of the frame with her back to the viewer, she does not stand out at first. In the centre of the frame there is another woman - a patient, who reads the following poem: "Doctor Ewa is a good woman, the sick praise her, that is her virtue. She has so many patients every morning, she is always so nice and everyone loves her". Only after a while, does Ewa turn away and then the viewer can see her for the first time. Patients writing poems devoted to their family doctors are rare, so the director must have been very lucky if this shot was accidental.

The film directed by Konopa was more edited than a television reality show. While in the case of programmes such as Big Brother the editing guarantees briefness (a TV station cannot afford a 24-hour long live transmission) and increases the audience-boosting tension, in the case of a documentary it is supposed to organize the logic of the director's reasoning; the shots constitute arguments explaining a thesis. The differences may also be observed while analysing the place of the action. The limited space - characteristic of a psycho gameshow ${ }^{29}$, to which the house of Konopa family and their places of work correspond - is often crossed (for example during home visits).

The relationship between the sender, the character and the viewer was also transformed in a certain way. In a reality show, the characters - condemned to hidden cameras - focus on interactions closed within the programme's structure. The authorial role is marginalized, the cameras and the intention to create an appropriate impression of oneself are what matters. In Konopa's documentary, the director is also the first recipient, and his presence is emphasized by the characters. The rivalry-inducing elements of the genre are eliminated, thus lowering the likelihood of conflict situations and controversial behaviour, which are present in the reality show.

\section{Closing remarks}

In the interview referred to at the beginning of this article, Fidyk observers that

Documentary film or television documentary has evolved owing to the popularity of the reality show. This pushed the limits of what is allowed. Before, only the documentary presented the truth. Suddenly, a primitive reality show emerged, in which people do everything and say everything - there is sex, toilet, shower - the cameras show everything ${ }^{30}$.

\footnotetext{
${ }^{29}$ The other name for a reality show.

${ }^{30}$ Reality show kontra film dokumentalny.
} 
The technology plays a major role in making the privacy public: "The new video technology makes it possible to go among the people in a nearly unnoticeable way, register what we see without interfering with the matter of reality"31. Such films would have never been made if an entire film crew had appeared in the characters' apartment. In spite of all that, there are still questions of an ethical nature, since the camera which invades the private space remains an intruder, an unnatural ingredient in this landscape. This is especially noticeable in those documentaries, in which one of the parents insists on switching off the device (i.e. Mama, Tata, Bóg i Szatan [Eng. My Mum, Dad, God and Satan], dir. Pawel Jóźwiak-Rodan, 2008). Deciding on such a film, the director must be aware of potential grudges and accusations on the part of the audience, who may perceive such documentaries as an attack on one's own family, taking the easy way in terms of searching for a topic or following the trend of selling everything

What will be the future of autobiographical documentary? Will the influences of the reality show still be so distinct? Uszyński claims that

Current exemplifications of the reality shows are most likely only the beginning of the genre's existence; one may expect - whether we like it or not - that it will have a great future. A multifunctional genre - which can satisfy very different expectations; polyphonic - relating to different customary patterns; flexible - easily generating subsequent mutations, that is containing the potential to evolve in different directions ${ }^{32}$.

Who knows, perhaps the further merging of this genre with documentary films will result in valuable productions?

\section{Bibliography}

Barczyk A., Fiołek-Lubczyńska B., "Film of facts and film of fictions - two pictures of catharsis in film”, a speech during International Congress in Comparative Studies „Human in Language, Literature, Culture" (Daugavpils, 14-16.11.2013 r.).

Barczyk A., Nolbrzak R., ,Przed kamera zamiast na kozetce u psychologa? Terapeutyczna funkcja polskich dokumentów autobiograficznych", a speech during Ogólnopolska Sesja Naukowa Kinoanaliza (Lodz, 22-24.11.2013 r.).

Fiołek-Lubczyńska B., „Tradycja i nowatorstwo współczesnego polskiego kina dokumentalnego (po 1989 r.) Bliżej rzeczywistości, bliżej człowieka...”, in: „O mediach i komunikacji. Skrypt dla studentów dziennikarstwa i komunikacji społecznej”, ed. E. Pleszkun-Olejniczakowa, J. Bachura, M. Worsowicz, Wydawnictwo Uniwersytetu Lódzkiego, Lodz 2010, pp. 217-230. Krzpiet M., „Fenomen ekshibicjonizmu w telewizji”, Impuls, Cracow 2005.

${ }^{31}$ T. Sobolewski, „Obiektyw życia”, Gazeta Wyborcza 2000, No. 69, p. 15.

32 J. Uszyński, op. cit., p. 131. 
Łuszczek K., „Nowoczesna telewizja, czyli bliskie spotkania z kulturą masową”, Maternus Media, Tychy 2004.

Mrozowski M., „Media masowe. Władza, rozrywka i biznes”, Oficyna Wydawnicza Aspra JR, Warsaw 2001.

Piotrowska A., „Wiwisekcja”, Tygodnik Powszechny 2000, No. 8, p. 13.

Przylipiak M., „Poetyka kina dokumentalnego”, $2^{\text {nd }}$ ed., en., rev. ed., Wydawnictwo Uniwersytetu Gdańskiego, Gdansk-Slupsk 2004.

„Reality show kontra film dokumentalny”, http://www.stopklatka.pl/wydarzenia/wydarzenie. asp?wi $=68883$ [access: 31.03 .2012 ].

Sobolewski T., „Obiektyw życia”, Gazeta Wyborcza 2000, No. 69, p. 15.

Sulima R., „Oko 'Wielkiego Brata”, in: „Podglądanie 'Wielkiego Brata”, ed. W. Godzic, Rabid, Cracow 2001, pp. 25-36.

Uszyński J., „Telewizyjny pejzaż genologiczny”, Telewizja Polska S.A. Centrum Strategii - Akademia Telewizyjna, Warsaw 2004.

Wimmer R.D., Dominick J.R., „Mass media. Metody badań”, transl. T. Karłowicz, Wydawnictwo Uniwersytetu Jagiellońskiego, Cracow 2008.

Wiśniewska A., „«Takiego pięknego syna urodziłam» Marcina Koszałki, czyli zaprzepaszczony potencjał krytyczny dokumentu autobiograficznego”, in: „Polskie kino dokumentalne 1989-2009. Historia polityczna”, ed. A. Wiśniewska, Wydawnictwo Krytyki Politycznej, Warsaw 2011, pp. 41-65.

http://www.filmpolski.pl/fp/index.php/4223470 [access: 3.04.2012].

Bogumiła Fiołek-Lubczyńska, Agnieszka Barczyk-Sitkowska

\section{The Condition of Polish Autobiographical Documentaries - More Similar to a Reality Show?}

\section{(Summary)}

The autobiographical documentary has a number of elements which resemble those of a reality show. Such documentaries can be considered to be young directors' responses to this TV genre and its celebration of voyeurism. The purpose of this article is to outline the similarities and differences between these two genres. The article consists of four parts: the first discusses the essence of the autobiographical documentary, the second focuses on the reality show, the third analyses the movie Moje dwadzieścia okrązeń by Łukasz Konopa, and the fourth is a summary of the considerations made in the text.

Keywords: film, film of fact, reality show. 